\title{
Herbicide 2,4-D: A Review of Toxicity on Non-Target Organisms
}

\author{
Ana Claudia de Castro Marcato • \\ Cleiton Pereira de Souza • Carmem Silvia Fontanetti
}

Received: 21 October 2016 / Accepted: 17 February 2017 / Published online: 2 March 2017

(C) Springer International Publishing Switzerland 2017

\begin{abstract}
The intensive use of pesticides has increased exponentially in Brazil and worldwide due to the need to meet the food demands of a growing population. If the management/monitoring of the use of pesticides is adequately performed, it would not compromise the expected benefits or have negative effects on the environment as a whole. In order to examine the information available on herbicide use in Brazil and worldwide, this paper presents a review of the herbicide 2,4dichlorophenoxyacetic acid (2,4-D) and its chemical properties, action on target organisms, environmental fate, and toxicity to non-target organisms. This herbicide is a synthetic auxin used to control broad-leaved weeds, and the action in target organisms is well known. Although 2,4-D has been widely used worldwide, many studies have shown that this herbicide induces alterations in non-target organisms. Therefore, ecotoxicology studies are important to assess the risk the herbicides can be to different ecosystems. Thus, it is advised to use this herbicide and other pesticides with caution.
\end{abstract}

Keywords Pesticides · Mutagenesis · Synthetic auxin · Agent Orange

A. C. de Castro Marcato - C. P. de Souza •

C. S. Fontanetti $(\square)$

Instituto de Biociências, Universidade Estadual Paulista (UNESP), Rio Claro, Brazil

e-mail: fontanet@rc.unesp.br

\section{Introduction}

Pollution can be classified as coming from point or nonpoint sources (Holt 2000). Point source pollution includes treatment plants of industrial effluents, domestic sewage, accidental spills, and mining. The emissions of point sources of pollution, usually as direct discharge of contaminants into water bodies, are more easily detected and controlled. On the other hand, non-point emissions are difficult to control, vary in time and space, and can involve pathways that result in partial accumulation of contaminants before reaching water bodies. A typical example of non-point source pollution is the use of pesticides in the soil (Costa and Olivi 2008).

Emissions of contaminants into the air, soil, and mainly water are associated with natural processes and mainly human activities. World population growth and increasing food demands have led to higher pesticide use in crops to prevent or control pests in order to increase yields (Caldas and Souza 2000). The first compounds used to manage pests or diseases were sulfur, lime, and some arsenic salts (Sanches et al. 2003).

The intensification of pesticide use in recent decades and their adverse effects on humans and the environment have led to the regulation of their use and production in several countries to minimize negative impacts to ecosystems. Each country created multidisciplinary committees and agencies with legal and managerial aspects to assess the level of danger and the risks that these products offer to humans and the environment (Zagatto and Bertoletti 2006). Pesticides are biocidal products used in agriculture to exterminate a pest. In 
this diversified group of chemical compounds are fungicides, insecticides, and herbicides considered extremely aggressive to the environment and to human health (Grisolia 2005).

After the Second World War, the number of new compounds and their extensive use in agriculture increased dramatically. With the rise of intensive monocrop systems and the decrease in diversity, several pests have evolved, which are then controlled with chemicals (Amarante 2002). Given that pesticides, such as herbicides, have contaminated the environment due to widespread use, assessment of the toxicity of these compounds is essential (Marin-Morales et al. 2013). These compounds have contaminated aquatic systems, and therefore monitoring groundwater, particularly near agricultural areas and sources of primary drinking water, is especially important (Sanches et al. 2003).

Despite the increase in crop yields, herbicide use can have serious ecological effects, contaminating receiving waters with toxic compounds and inhibiting biological treatment systems, even at low concentrations (MarrónMontiel et al. 2006). The application of pesticides is not often uniform, even when using modern equipment. Because of this, and also because of the different stages in which pests can be found, the doses can be lethal or sublethal. Thus, the pest population that received sublethal doses can present a significant amount of DNA mutations due to stress induced by pesticide application, leading to pesticide resistance (Gressel 2011).

Considering the problem of indiscriminate and increasing use of pesticides, which offers serious risks to the environment and biodiversity, this paper aims to provide an overview on the herbicide 2,4dichlorophenoxyacetic acid (2,4-D) and its chemical properties, action on target organisms, environmental fate, and toxicity in animals and higher plants bioindicators, evaluated by histological, histochemical, and genetic biomarkers.

\section{Chemical Properties, Action on Target Organisms, and Environmental Fate of the Herbicide 2,4-D}

The basic formulation of 2,4-D is an acid, but 2,4-D is produced as an inorganic salt, amine, or ester through various production processes, and it is used in many commercial products. The molecular formula of 2,4-D is $\mathrm{C}_{8} \mathrm{H}_{6} \mathrm{Cl}_{2} \mathrm{O}_{3}$ (Fig. 1), with a molecular weight of 221.04 ,

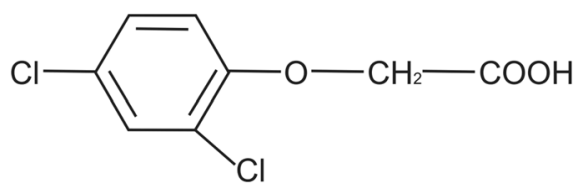

Fig. 1 Chemical structure of 2,4-dichlorophenoxyacetic acid

melting point of $140.5^{\circ} \mathrm{C}$, boiling point of $130^{\circ} \mathrm{C}$, and water solubility of $900 \mathrm{mg} / \mathrm{L}$ at $25^{\circ} \mathrm{C}$ (acid) (Kennepohl and Munro 2001).

According to Wang et al. (1994), the octanol-water partition coefficient $\left(K_{\mathrm{ow}}\right)$ of 2,4-D has a large difference in amounts partitioned to water phase between presence at the ionic state and at the molecular state. In a higher $\mathrm{pH}$ solution, the $K_{\mathrm{ow}}$ is 0.027 , and in a lower $\mathrm{pH}$ solution the $K_{\text {ow }}$ is 18.23 , implying that the $\mathrm{pH}$ value might affect the bioaccumulation process of 2,4-D.

Many derivatives of chlorinated phenoxyacetic acids are classified as plant growth regulators or hormones that act as synthetic auxins. These derivatives are widely used as herbicides and include 2,4-D (Kumari and Vaidyanath 1989; Filkowski et al. 2003). These herbicides have a similar effect to natural auxin indoleacetic acid (IAA) in most plants; however, they have long duration due to their high stability in the plant, so they are more effective than IAA. Auxin herbicides have direct action because they induce ethylene biosynthesis through the synthesis of ACC (1-aminocyclopropane-1carboxylic acid). Additionally, in the indirect pathway of action, ethylene stimulates production of abscisic acid (ABA). ABA inhibits cell division and expansion, and ethylene promotes leaf senescence. Inhibition of growth, tissue damage, and cell and plant death are the consequences (Grossmann 2003).

Synthetic auxins, such as 2,4-D, persist for long periods in the plant and consequently are effective and lethal. The mode of action of auxin herbicides is dose dependent, and its effect also depends on the sensitivity of tissues and species (Pazmiño et al. 2012). While the concentration of natural auxins and their effects are strictly controlled, auxin herbicides bypass the natural regulatory mechanisms of susceptible plants and cause an uncontrolled response to auxin. In low doses, auxin herbicides have hormone properties similar to those of natural auxins. However, higher concentrations cause several growth abnormalities in sensitive dicotyledons (Kelley and Riechers 2007). The mode of action of 2,4$\mathrm{D}$ is characterized by an increase in plasticity of the cell wall and abnormal increase of the synthesis of proteins and ethylene, resulting in uncontrolled cell division and 
damage to the vascular tissue of plants (USEPA 2005). Therefore, because of its chemical resemblance to auxins, 2,4-D overstimulates growth, culminating in the death of the target plant (Oruç et al. 2004; Benli et al. 2007).

2,4-D is not considered persistent in the terrestrial environment because it is just adsorbed to soil particles when there is a high rate of organic carbon (Walters 1999). However, 2,4-D is not easily biodegradable in aquatic environments (Chingombe et al. 2006) and is frequently detected in water bodies as a free anion. The decomposition of this anionic form occurs mainly by microbial degradation. Biodegradation in water depends on several factors, including temperature and the availability of oxygen and nutrients (Walters 1999).

The 1988 2,4-D Standard Registration established the environmental fate relating to the degradation of 2,4-D to 2,4-D esters and 2,4-D amine salts to 2,4-D acid. Data indicate that 2-4-D esters are rapidly hydrolyzed in aquatic environments and alkaline wet soils. However, 2,4-D ester may be persistent in acid aquatic environments and dry soils. In most environmental conditions, rapid degradation of 2,4-D esters and amine salts to 2,4-D acid occurs (USEPA 2005).

According to Kennepohl and Munro (2001), the carcinogenic effect of 2,4-D has not been demonstrated. This information was corroborated by the United States Environmental Protection Agency (USEPA 2005), which classified the herbicide as a Group D herbicide (non-classifiable as a human carcinogen) due to the lack of evidence as a carcinogen.

\section{Use of the Herbicide 2,4-D in Brazil and Worldwide}

The development of 2,4-D and other phenoxyacetic herbicides transformed agriculture in much of the world and should be classified as a major contribution of science (Zimdahl 2010). The application of auxin herbicides began a new phase in agricultural production due to its systemic mobility in the plant and its selective action, mainly against dicotyledonous weeds (Grossmann 2003). 2,4-D has been widely used worldwide (WHO 1984) in a large scale in the control of broad-leaved weeds since the beginning of the 1940s (Grisolia 2005; Itoh et al. 2013). In the past, 2,4-D mixed with 2,4,5-T was used for weed control (Wolfe 1984). More than 10 million gallons of this mixture, known as Agent Orange, in a 1:1 ratio (Mortelmans et al. 1984) was used in the Vietnam War to defoliate trees (Wolfe 1984).

Although 2,4-D is one of the most successful widely used herbicides, its intensive use has resulted in resistant weeds and many contamination issues when present in concentrations higher than those recommended (Teixeira et al. 2007). The herbicide 2,4-D was introduced in the 1940s, and after more than 50 years of use, it is still the most widely used throughout the world. It is mainly applied in wheat, sorghum, corn, rice, sugarcane, soybeans, and pastures (Mičić et al. 2004).

According to the Brazilian Ministry of Agriculture, Livestock and Farm Supplies (Ministério da Agricultura, Pecuária e Abastecimento) (MAPA 2017), there are 24 commercial formulations that include 2,4-D as an active ingredient, either alone or in combination with two other herbicides, aminopyralid and picloram. The reports of the Brazilian Institute for Environment (Instituto do Meio Ambiente e Recursos Naturais Renováveis) (IBAMA 2016) show that between 2009 and 2012 the 2,4-D was the third/fourth active ingredient of most pesticides sold in Brazil, and after 20132014 it was the second best-selling active ingredient in the country; on that basis, it can be noted that 2,4-D was the best-selling selective herbicide in the country between 2009 and 2014.

The concentrations of 2,4-D recommended for the control of weeds predominant in Brazilian agricultural cultivars are presented in Table 1.

\section{Toxicity of 2,4-D to Different Organisms}

Pesticides are different from other chemicals because they are applied in the environment to control unwanted living species. Therefore, they have to be biologically active and for this reason are characterized by different degrees of toxicity. Since this toxicity is not always specific to the target organisms, the use of pesticides can present risks to human health, survival of non-target species, and the environment (Colosio and Moretto 2008). In view of the use of these substances on a large scale, investigation of the toxicity in various environments is necessary and prudent since it can affect different organisms.

When animals experience acute exposure to different compounds, by inhalation or by the presence of the toxicant in the environment in which the organism lives, 
Table 1 Dosage of 2,4-D used in Brazilian crops for weed control

\begin{tabular}{|c|c|c|}
\hline Crop & Dose of $2,4-\mathrm{D}(\mathrm{kg} / \mathrm{ha})$ & Target plant \\
\hline Wheat & $0.32-1.005$ & $\begin{array}{l}\text { Bidens pilosa } \\
\text { Commelina benghalensis } \\
\text { Euphorbia heterophylla } \\
\text { Galinsonga parviflora } \\
\text { Ipomoea grandifolia } \\
\text { Ipomoea purpurea } \\
\text { Raphanus raphanistrum } \\
\text { Sida rhombifolia } \\
\text { Sonchus oleraceus }\end{array}$ \\
\hline Corn & $0.403-1.209$ & $\begin{array}{l}\text { Acanthospermum hispidum } \\
\text { Aeschinomene rudis } \\
\text { Alternanthera tenella } \\
\text { Amaranthus deflexus } \\
\text { Amaranthus viridis } \\
\text { B. pilosa } \\
\text { C. benghalensis } \\
\text { E. heterophylla } \\
\text { Emilia sonchifolia } \\
\text { G. parviflora } \\
\text { I. grandifolia } \\
\text { I. purpurea } \\
\text { Portulaca oleracea } \\
\text { R. raphanistrum } \\
\text { Richardia brasiliensis } \\
\text { S. rhombifolia }\end{array}$ \\
\hline Soy & $0.67-1.209$ & $\begin{array}{l}\text { B. pilosa } \\
\text { C. benghalensis } \\
\text { E. heterophylla } \\
\text { I. grandifolia } \\
\text { I. purpurea } \\
\text { R. raphanistrum } \\
\text { R. brasiliensis } \\
\text { S. rhombifolia } \\
\text { Spermacoce latifolia }\end{array}$ \\
\hline
\end{tabular}

Rice

$0.403-1.209$

Irrigated rice

$0.201-1.209$

Sugarcane

$0.403-2.345$
Table 1 (continued)

\begin{tabular}{ll}
\hline Crop $\quad$ Dose of 2,4-D (kg/ha) & Target plant \\
\hline A. tenella \\
A. viridis \\
B. pilosa \\
C. bengalensis \\
E. heterophylla \\
E. sonchifolia \\
G. parviflora \\
I. grandifolia \\
I. purpurea \\
P. oleracea \\
R. brasiliensis \\
R. raphanistrum \\
S. rhombifolia \\
A. deflexus \\
B. pilosa \\
Conyza bonariensis \\
Croton glandulosus \\
Cyperus rotundus \\
E. heterophylla \\
Momordoca charantia \\
P. oleracea \\
S. rhombifolia \\
Sida cordifolia \\
Sida glaziovii \\
Solanum americanum \\
Solanum brasiliensis \\
Solanum palinacanthum \\
A. hispidum \\
Ageratum conyzoides \\
A. deflexus \\
Amaranthus hybridus \\
Amaranthus spinosus \\
A. viridis \\
Brassica rapa \\
C. benghalensis \\
E. heterophylla \\
G. parviflora \\
I. aristolochiaefolia \\
I. purpurea \\
Leonorus sibiricus \\
P. oleracea \\
C.806-2.821 \\
\end{tabular}

Table adapted from the guidelines of manufacturers of the DMA 806 BR, Dow AgroSciences; Aminol 806, Adama; 2,4-D Nortox, Nortox S.A.

such as fish (water) and earthworms (soil), the dose absorbed by the animals is generally unknown; thus, the concentration of the toxicant in the environment capable of causing $50 \%$ death of the individuals is expressed as lethal concentration $50\left(\mathrm{LC}_{50}\right)$ (Klaassen 2013, p. 34). The traditional acute toxicity test is usually performed to determine the $50 \%$ lethal dose $\left(\mathrm{LD}_{50}\right)$, that is, the absorbed dose of a given compound required for the death of $50 \%$ of the exposed organisms. The $\mathrm{LD}_{50}$, therefore, is based on statistical calculations, which 
represent a theoretical Gauss curve, with a confidence limit of $95 \%$, of the dose-response relation of an exposed population, which is rarely found in practice (OGA et al. 2014, p. 30). Acute toxicity tests provide information necessary for the experimental design of different bioassays in vitro and in vivo.

The lethal doses and concentrations of 2,4-D vary among species. Eisenia foetida have a 14-day $\mathrm{LC}_{50}$ of $350 \mathrm{mg} / \mathrm{kg}$ soil (WHO 1997). Daphnia (Daphnia magna) have an $\mathrm{LC}_{50}$ of greater than $100 \mathrm{mg} / \mathrm{L}$ (Heggstrom 2009). The $\mathrm{LC}_{50}$ value for Nile tilapia (Oreochromis niloticus L.) adults was found to be $86.90 \mathrm{mg} / \mathrm{L}$ (Sarikaya and Selvi 2005). The $\mathrm{LC}_{50}$ ranged from 250 to greater than $600 \mathrm{mg} / \mathrm{L}$ for fathead minnows (Pimephales promelas), bluegills (Lepomis macrochirus), and rainbow trout (Salmo gairdneri). The single-dose dermal $\mathrm{LD}_{50}$ exceeded $2000 \mathrm{mg} / \mathrm{kg}$ in rabbits (Gorzinski et al. 1987). The $\mathrm{LD}_{50}$ of a single oral dose in rats ranged from 553 to $1090 \mathrm{mg} / \mathrm{kg}$ (Gorzinski et al. 1987). Dogs are more sensitive to an oral $\mathrm{LD}_{50}$ of $100 \mathrm{mg} / \mathrm{kg}$ (Bovey and Young 1980; Garabrant and Philbert 2002).

Pesticides have been the focus of ecotoxicological studies, as they contaminate the atmosphere, water, and soil; persist in the environment; enter ecological chains; and have adverse toxic effects on organisms from bacteria to humans. Evaluation of the impact of pesticide use on non-target organisms is conducted with different tests. Small mammals, birds, soil microorganisms, pollinator insects (bees and wasps), and aquatic organisms (fish, zooplankton, phytoplankton, and microcrustaceans) are considered representative organisms for these different tests (Grisolia 2005).

The use of herbicides in agricultural crops can cause health problems due to their persistence in the environment and accumulation throughout the food chain. Food is the main route for exposure of humans to these chemicals, and fish and shellfish have been recognized as major vectors for contaminant transfer to humans (Ateeq et al. 2006). 2,4-D can cause several metabolic alterations and tissue necrosis in non-target organisms, including important members of the food chain (Gallagher and Di Giulio 1991).

2,4-D is quickly absorbed in the gastrointestinal tract after oral exposure; the agrochemical residues can be observed in plasma levels from $10 \mathrm{~min}$ to $24 \mathrm{~h}$ after exposure, depending on the dose and the chemical form of 2,4-D (Knopp and Schiller 1992). The absorption of 2,4-D ester has been reported to be slower than 2,4-D acid and salt (Erne 1966), but their excretion rates are similar (Knopp and Schiller 1992).

According to Bécaert et al. (2006), 2,4-D has a negative effect on the soil by directly inhibiting or removing a source of enzyme production (bacteria). This inhibiting effect results in the loss of functional stability of urease, $\beta$-glucosidase, and sulfatase, affecting soil stability due to changes in the functional mechanisms of resistance and recovery. In laboratory tests with Eisenia fetida (Annelidae), 2,4-D had serious effects on development and reproduction. The toxic effects observed after exposure of animals to 2,4-D-contaminated soils were more severe than those observed for animals exposed to the herbicide glyphosate in the same concentration (Correia and Moreira 2010).

Hoy (1985) exposed Scytonotus simplex (millipede) to three different doses of 2,4-D in three different ways in the soil (applied evenly in the substrate, applied in half of the substrate, and added to half of the food provided) and made comparisons to a control group. In the control group, mortality was not observed until the 10th day, while in treatment groups mortality was observed within 2 days of the experiment and progressively increased during the first 10 days. Comparisons among the three methods of application of 2,4-D suggest that this species of millipede avoids surfaces treated with 2,4-D and that the spatial distribution of 2,4-D residues in the field can influence the effect of the herbicide on the animal. A uniform distribution, contaminating a wide portion of the soil, seems more harmful than an irregular one.

According to Gallagher and Di Giulio (1991), this herbicide is usually considered non-toxic to fish in low concentrations. However, Fonseca et al. (2008) reported that 2,4-D affects the brain and activity of the enzyme acetylcholinesterase in the muscles and some metabolic parameters of the blood and tissues of Leporinus obtusidens, possibly due to the stress caused by the toxicity of this herbicide. Sarikaya and Yilmaz (2003) also described 2,4-D as highly toxic to fish, with serious effects to humans and animals, since it accumulates in tissues and causes acute poisoning (WHO 1984).

Ateeq et al. (2006) conducted a histological analysis of the gonads and liver of fish of the species Clarias batrachus to examine DNA fragmentation, and they confirmed the genotoxic effect of 2,4-D. In the histological analysis of the gonads, in the ovaries, this herbicide induced apoptosis, indicated by the presence of atretic oocytes, nuclear blebbing, karyolysis, hypertrophy, and 
vacuolation, in addition to mitochondrial deformities, electron-dense cytoplasm, damage to the plasma membrane, vacuolation, and heterochromatinization. In the testicular tissue, the tubules were relatively smaller in size and contained mainly spermatids. Some cells in the seminiferous tubules had signs of necrosis characterized by dissolution of the nucleus and nuclear membrane. Leydig cells were slightly hypertrophied, which may be a response to an increase in the functional demand, confirming the genotoxic effect of 2,4-D.

Cattaneo et al. (2008) reported that fish of the species Rhamdia quelen exposed to 2,4-D exhibited some behavioral alterations, such as lethargy and erratic swimming. The histological analysis of the liver revealed alterations after exposure, such as abnormal arrangement of hepatic cords, rupture of the cell membrane, and vacuolation in hepatocytes. The fish species Geophagus brasiliensis subjected to concentrations of 1, 5, 10, 20, 40, and $80 \mathrm{mg} / \mathrm{L}$ of 2,4-D for $96 \mathrm{~h}$ presented changes in mortality rates, oxygen consumption, and ammonia excretion. Mortality rates were directly proportional to the concentrations of the herbicide, reaching $100 \%$ at a concentration of $80 \mathrm{mg} / \mathrm{L}$. Oxygen consumption rates change significantly in higher concentrations, which may result in changes in energy metabolism. The ammonia excretion rates were inversely proportional to the concentrations exposed, revealing changes in the animal's metabolism that may result in the excretion of the toxic substances absorbed. The mean neutral red retention team was significantly lower in comparison to the control, and the decrease of the dye retention team was directly related to the increase of the 2,4-D concentration (Barbieri 2009).

Tayeb et al. (2010) assessed the toxicity of 2,4-D administered to rats via oral gavage and observed prominent alterations in the liver tissue. After 4 weeks, animals treated with $15 \mathrm{mg} / \mathrm{kg}$ of 2,4-D exhibited ruptured hepatic cords in several areas. Focal necrosis was also observed, as well as vacuolation in hepatocytes and vessel dilation. These alterations were more prominent after treatment with a $75 \mathrm{mg} / \mathrm{kg}$ dose. Necrosis was more frequently observed in the group treated with this concentration, in addition to increase in glycogen charge. The treatment with $150 \mathrm{mg} / \mathrm{kg}$ of 2,4-D induced other histopathological alterations, such as pyknotic nuclei, congestion of hepatocytes, significant increase of cells undergoing necrosis, vacuolated hepatocytes, and loss of the typical polyhedral shape.
Ruptured hepatic cords were also observed in several areas, demonstrating subacute toxicity to the liver caused by 2,4-D.

In order to investigate the effects of 2,4-D on testicular morphology and function, dwarf goats received three different treatments with the herbicide. The results revealed alterations in the seminiferous tubules, such as hyperemia and stromal edema, and detachment of the basal membrane from the surrounding fibromuscular layer. A reduction in the number of Sertoli cells, with vascular alterations of the intertubular stroma, was present in all treated groups, characterizing lower reproduction rates. Thus, exposure to 2,4-D negatively affected sperm counts of individuals, which might cause sperm dysfunction in humans and other species exposed to this toxic compound when applied to agricultural crops (Obidike et al. 2012). However, epidemiological data reported in some studies do not provide sufficient evidence that the herbicide is toxic to human sperm cells (Burns and Swaen 2012). In addition, other studies have reported that 2,4-D induced chromosome aberrations, also confirming its genotoxic/mutagenic effect (Tukula and Jalal 1985; Mustonem et al. 1986; Kale et al. 1995). Pesticides are bioactive molecules that tend to form electrophilic metabolites capable of reacting and combining with biological macromolecules, thus potentially predisposing the genetic material to changes through covalent bonds (Rodrigues 2002).

Taking into account the wide use of 2,4-D, we can infer how harmful the presence of this herbicide may be to non-target organisms. This compound, although useful for agriculture, may in the long term cause a change in soil since studies have shown disturbance of soil fauna, such as earthworms and millipedes, when exposed to 2,4-D, thereby altering the quality of the soil. Although this herbicide is applied to the soil, its drain occurs for the different types of water bodies, thus damaging aquatic animals. The consequences of its presence in the aquatic environment can interfere in the whole food chain since there are reports of the accumulation of this substance in the tissues of fish. Although there are no studies demonstrating its chronic toxicity in humans, the exposure of other mammals reveals how harmful the herbicide is and its ability to interfere with the physiology of animals. In view of this, a concern is raised about the correct use of this 
compound in cultivated areas since its effects reach beyond the proposed target.

Bioassays with plants have been considered adequate for the assessment of genotoxicity and mutagenicity, mainly due to ethical reasons. Besides that, the assays with these bioindicators are validated and recommended, and their protocols are standardized by different environmental institutions, including the United Nations Environment Programme, the US Environmental Protection Agency, and the World Health Organization. Many higher plants are frequently used to monitor environmental pollutants (Leme and Marin-Morales 2009; Iqbal 2016; de Souza et al. 2016). According to Ma et al. (1995), plants are direct biological receptors of pollutants, and they constitute an important tool for genetic tests and environmental monitoring.

Croker (1953) reported that 2,4-D caused alterations during mitosis in Allium cepa. Alterations were dose dependent and classified as structural or physiological. The latter, such as adherence, chromosome condensation, and delay in the formation of the mitotic fuse, were observed after $2 \mathrm{~h}$ of treatment. Structural alterations include chromatid breaks, observed after 2 to $4 \mathrm{~h}$ of exposure to higher concentrations. Chromosome breaks were observed in groups exposed to all concentrations. Therefore, 2,4-D affects the nucleic acid cycle, suggesting that its effect on the chromosome structure is analogous to that of radiations.

Fiskesjö et al. (1981) studied the effects of 2,4-D by Allium test. They found that the mitotic index decreased in all concentrations tested and noticed a swelling in the roots (C-tumor) at a concentration of $1 \mathrm{ppm}$. Polyploid cells and giant cells were also seen. Pavlica et al. (1991) also examined the effects of two different concentrations of 2,4-D on A. cepa, 45 and $450 \mu \mathrm{M}$; they observed that after 2 and $24 \mathrm{~h}$ of treatment $+24 \mathrm{~h}$ of tap water, the concentration of $45 \mu \mathrm{M}(\mu \mathrm{g} / \mathrm{mL})$ decreased the mitotic activity almost three times lower than compared to the control group. On the other hand, the concentration of $450 \mu \mathrm{M}$ stimulated cell division; the induction of chromosomal aberrations was much higher in the concentration of $450 \mu \mathrm{M}$. 2,4-D had a prominent effect on the mitotic fuse. Most of the abnormalities found were Cmitosis, disturbances in the anaphase, and problems in the reconstitution of the nucleus. The herbicide caused chromosome alterations during metaphase, anaphase, and telophase, except for micronuclei that were observed mainly in interphase. Chromosome bridges during anaphase and telophase were found after 2 and $24 \mathrm{~h}$ of treatment with $450 \mu \mathrm{M}$, and laggards were also observed, although in low frequency. The most frequently observed alteration was micronuclei in the groups exposed to the two concentrations. Chromosome adherence was also frequently observed and accompanied by instability of the mitotic fuse and chromosome. Fragmentation of the chromatin in interphase nuclei was observed in the group exposed to the highest concentration, as chromatin bodies.

According to Ateeq et al. (2002), onion bulbs exposed to different concentrations of 2,4-D, especially 25-100 ppm, exhibited prominent alterations associated with general growth and cell shape, in addition to a mitotic index near zero. In doses ranging from 5 to 20 ppm, a "Crochet hook," C-tumors, and swelling were observed in roots. In the group exposed to $1-4 \mathrm{ppm}$ used for the chromosome aberration test, this parameter could not be calculated effectively since the roots were short (3-5 mm).

Assessment of the genotoxic effects of Avenoxan ${ }^{\circledR}$, a commercial formula of 2,4-D in A. cepa and Allium sativum, revealed that the decrease in mitotic index in the two species had a dose-response effect. All concentrations induced abnormalities during mitotic division compared to the negative control in both species. The abnormalities were C-mitosis, adherences, anaphases and telophases with a bridge, lost chromosomes, multipolar anaphase, micronucleus, and breaks, the most common being C-mitosis (Gul et al. 2006).

Genotoxicity studies on 2,4-D in transgenic plants (Arabidopsis thaliana) demonstrated that the increase in concentration of the herbicide from $0-3$ to $0-30 \mu \mathrm{g} / \mathrm{L}$ increased the frequency of transitions $A \rightarrow G$ when compared with the control group. The increase from 100 to $300 \mu \mathrm{g} / \mathrm{L}$ in the concentration of 2,4-D resulted in a decrease in the frequency of recombination. Interestingly, no effects of 2,4-D were observed on the frequency of transversions $\mathrm{T} \rightarrow \mathrm{G}$. The increase in the frequency of recombination in low concentrations was associated with the increase of the levels of point mutations $\mathrm{A} \rightarrow \mathrm{G}$. Thus, in general, 2,4-D in lower concentrations had a strong effect on recombination. However, this trend was not observed in higher concentrations (Filkowski et al. 2003).

A study by Grabinska-Sotaa et al. (2003) on the toxicity of derivatives of synthetic auxins to broadleaved plants and grains demonstrated that phenoxyacetic herbicides inhibited root growth. However, grasses in general were less sensitive to $2,4-\mathrm{D}$ 
Table 2 Summary of studies of the toxicity of 2,4-D to different organisms

\begin{tabular}{|c|c|c|c|}
\hline Organism & Dosage of 2,4-D & Author & Effects in organisms \\
\hline Bacteria & $36 \mathrm{mg} / \mathrm{kg}$ of soil & $\begin{array}{l}\text { Bécaert et al. } \\
\quad(2006)\end{array}$ & $\begin{array}{l}\text { Negative effect on soil, maybe for right inhibition or } \\
\text { remotion of bacteria }\end{array}$ \\
\hline Eisenia foetida & $\begin{array}{l}1,10,100,500,1000 \mathrm{mg} / \mathrm{kg} \\
\quad \text { of soil }\end{array}$ & $\begin{array}{l}\text { Correia and } \\
\text { Moreira } \\
(2010)\end{array}$ & $\begin{array}{l}\text { High mortality rate, severe effect on the development and } \\
\text { reproduction }\end{array}$ \\
\hline Scytonotus simplex & $\begin{array}{l}\text { Four doses and different forms } \\
\text { of application of } 2,4-\mathrm{D}\end{array}$ & Hoy (1985) & $\begin{array}{l}\text { High mortality rate and influence of spatial distribution of } \\
\text { 2,4-D residues in the field }\end{array}$ \\
\hline Leporinus obtusidens & $1,10 \mathrm{mg} / \mathrm{L}$ & $\begin{array}{l}\text { Fonseca } \\
\quad \text { et al. } \\
\quad(2008)\end{array}$ & $\begin{array}{l}\text { Effect in the brain and in the activity of the muscle enzyme } \\
\text { acetylcholinesterase (AChE) and some metabolic } \\
\text { parameters of blood and tissue }\end{array}$ \\
\hline Cyprinus carpio & Varied doses of 2,4-D & $\begin{array}{l}\text { Sarikaya and } \\
\text { Yilmaz } \\
\text { (2003) }\end{array}$ & High toxicity to fish \\
\hline Clarias batrachus & $75 \mathrm{ppm}$ & $\begin{array}{l}\text { Ateeq et al. } \\
\quad(2006)\end{array}$ & $\begin{array}{l}\text { Genotoxic effect and histopathological alterations in male } \\
\text { and female gonads }\end{array}$ \\
\hline Rhamdia quelen & 1 to $780 \mathrm{mg} / \mathrm{L}$ & $\begin{array}{l}\text { Cattaneo } \\
\text { et al. } \\
(2008)\end{array}$ & Behavior alterations and histopathological alterations \\
\hline Geophagus brasiliensis & $1,5,10,20,40$, and $80 \mathrm{mg} / \mathrm{L}$ & $\begin{array}{r}\text { Barbieri } \\
(2009)\end{array}$ & $\begin{array}{l}\text { Changes in mortality rates, oxygen consumption, and } \\
\text { ammonia excretion }\end{array}$ \\
\hline Mouse & $\begin{array}{l}\text { Oral treatment at doses of } 15 \text {, } \\
75 \text {, and } 150 \mathrm{mg} / \mathrm{kg}\end{array}$ & $\begin{array}{l}\text { Tayeb et al. } \\
\text { (2010) }\end{array}$ & Marked alterations of hepatic tissue \\
\hline $\begin{array}{l}\text { West African Dwarf (WAD) } \\
\text { goats (male) }\end{array}$ & $\begin{array}{l}75,100 \text {, and } 125 \mathrm{mg} / \mathrm{kg} \text { body } \\
\text { weight }\end{array}$ & $\begin{array}{l}\text { Obidike et al. } \\
\text { (2012) }\end{array}$ & $\begin{array}{l}\text { Histopathological alterations in testicular tissue and loss of } \\
\text { effectivity of animal reproduction }\end{array}$ \\
\hline Allium cepa & $\begin{array}{l}25,125,250,500,1000,2500 \\
5000 \mathrm{ppm}\end{array}$ & $\begin{array}{l}\text { Croker } \\
(1953)\end{array}$ & Structural and physiological alterations in mitosis \\
\hline Allium cepa & $0.001,0.01,0.1,1 \mathrm{ppm}$ & $\begin{array}{l}\text { Fiskesjö } \\
\quad \text { et al. } \\
(1981)\end{array}$ & $\begin{array}{l}\text { Mitotic index decreased, C-tumor, polyploid cells, and giant } \\
\text { cells }\end{array}$ \\
\hline Allium cepa & $4,5,450 \mu \mathrm{M}$ & $\begin{array}{l}\text { Pavlica et al. } \\
\quad \text { (1991) }\end{array}$ & Strong effect on the mitotic fuse \\
\hline Allium cepa & $\begin{array}{l}1,2,3,4,5,10,15,20,25,50 \\
75,100 \mathrm{ppm}\end{array}$ & $\begin{array}{l}\text { Ateeq et al. } \\
\qquad(2002)\end{array}$ & $\begin{array}{l}\text { Alterations in general growth and in cell shape, C-tumors, } \\
\text { and swelling in roots }\end{array}$ \\
\hline Arabidopsis thaliana & $\begin{array}{l}0,5,10,30,100,200 \\
300 \mu \mathrm{g} / \mathrm{L}\end{array}$ & $\begin{array}{l}\text { Filkowski } \\
\text { et al. } \\
(2003)\end{array}$ & $\begin{array}{l}\text { Strong effect on the recombination in minor concentrations } \\
\text { tested }\end{array}$ \\
\hline $\begin{array}{l}\text { Sinapis alba, Lepidium } \\
\text { sativum, Avena sativa, } \\
\text { Triticum aestivum }\end{array}$ & $\begin{array}{l}0.3,1.5,3,30,150,300,3000 \\
0.072,0.72,7.2,36,72 \\
7200 \mathrm{mg} / \mathrm{L}\end{array}$ & $\begin{array}{l}\text { Grabinska- } \\
\text { Sotaa } \\
\text { et al. } \\
(2003)\end{array}$ & Inhibition of root growth \\
\hline Hordeum vulgare & 1 or $2 \mathrm{~L} / \mathrm{ha}$ & $\begin{array}{l}\text { Geras'kin } \\
\text { et al. } \\
\text { (2005) }\end{array}$ & Cytogenetic aberrations \\
\hline Allium cepa, Allium sativum & $0.1,0.2,0.4 \%$ & $\begin{array}{r}\text { Gul et al. } \\
(2006)\end{array}$ & $\begin{array}{l}\text { Decrease in mitotic index, induces C-mitosis, adhesions, } \\
\text { anaphases and telophases with bridge, lost chromosomes, } \\
\text { multipolar anaphase, micronucleus, and breaks }\end{array}$ \\
\hline Triticum aestivum & $\begin{array}{l}50,100,200,400,800 \\
1200 \mathrm{ppm}\end{array}$ & $\begin{array}{l}\text { Kumar et al. } \\
\text { (2010) }\end{array}$ & $\begin{array}{l}\text { Reduction the mitotic index and induction of chromosomal } \\
\text { abnormalities }\end{array}$ \\
\hline Phaseolus vulgaris & $0.1,0.2,0.3 \mathrm{ppm}$ & $\begin{array}{l}\text { Cenkci et al. } \\
\text { (2010) }\end{array}$ & $\begin{array}{l}\text { Reduction in root growth, increased soluble protein and the } \\
\text { number of bands in RAPD tests }\end{array}$ \\
\hline
\end{tabular}


derivatives, and therefore the toxicity of herbicide derivatives was higher for broad-leaved plants than for grasses. In a study on the cytogenetic effects of 2,4-D in $50 \%$ water (1-2 L/ha) on Hordeum vulgare (barley), Geras'kin et al. (2005) reported that the minimum dose increased the occurrence of cytogenetic aberrations nearly fourfold. Although significant, this effect was not dose dependent, as the frequency of cells with aberrations did not change significantly when the herbicide dose was doubled.

Kumar et al. (2010) reported that 2,4-D reduced the mitotic index of wheat plants, with a dose-dependent response. The variety HUW 468 exhibited the highest frequency of abnormal cells at the concentration of $1200 \mathrm{ppm}$ of the herbicide. The induction of chromosome abnormalities was also dose dependent in all treatments. The most common aberrations observed were adherence and bridges, but also multipolarity, in addition to laggards in response to the maximum dose of the herbicide in all varieties.

A study that evaluated the genotoxicity of 2,4-D in bean seedlings using the comet assay and RAPD (random amplified polymorphic DNA) reported that genomic template stability and root growth were reduced in the treatments compared with the negative control. An increase in total soluble proteins was observed in seedlings exposed to $2,4-\mathrm{D}$, contrary to the decrease observed in the positive control group. Damage to DNA assessed with the comet assay was substantially higher than that of the negative control in all treatment groups. Patterns of RADP also exhibited significant differences between the negative control and the treatment groups, with disappearance of a normal band and/or appearance of an additional band. Thus, the number of bands increased with the increase in the concentration of the auxin herbicide, demonstrating a dose-dependent effect (Cenkci et al. 2010).

In the studies reviewed here about the action of 2,4-D in plant bioindicators, it is observed that although this herbicide has its main mode of action in plants, based on physiological processes, since it is a synthetic auxin, 2,4-D may also interact with plant DNA; in all the studies reviewed, it was able to induce some level of change in the genetic material. The studies present changes in mitotic index and induction of chromosomal aberrations, mutations, and micronuclei, which are widely recognized genetic biomarkers of the action of different compounds in these bioindicators. The studies presented above are summarized in Table 2 for better visualization and comparison of data.

In this way, it is worth noting that different types of organisms are currently used as bioindicators, that is, sentinel species that are used as indicators to evaluate the environmental quality of the possible effects of natural risks or anthropogenic origin. Thus, the studies reviewed, using different animals and higher plants, to investigate the effects of 2,4-D, and analysis of the results showed that although the herbicide is effective when used in broad-leaved plants, it can endanger the different ecosystems.

\section{Final Considerations}

Even in low concentrations, 2,4-D may have cytotoxic, genotoxic, and mutagenic effects on plants, as well as histological, physiological, and behavioral alterations in animals. Thus, the studies presented here reinforce the warning that pesticides, although important for agriculture, need to be used more cautiously, applied only in the indicated amounts and, as far as possible, replaced by other methods less harmful to the environment and biodiversity.

Acknowledgements This research was supported by CAPES (Higher Education Personnel Training Coordination), CNPq (National Council for Scientific and Technological Development), and FAPESP (São Paulo Research Foundation) (processes no. 2011/14881-3, 2012/50197-2, and 2014/23919-2). The authors would like to thank Cintya Aparecida Christofoletti and Geraldo Stachetti Rodrigues for their collaboration.

\section{References}

Amarante, J. O. P. (2002). Avaliação do potencial de contaminação por herbicidas: determinação do 2,4-D e do seu principal produto de degradação em solos de campos de cultivo de eucaliptos. Thesis Master of Science Universidade Federal do Maranhão-Brazil.

Ateeq, B., Farah, M. A., Ali, M. N., \& Ahmad, W. (2002). Clastogenicity of pentachlorophenol, 2,4-D and butachlor evaluated by Allium root tip test. Mutation Research, 514, 105-113.

Ateeq, B., Farah, M. A., \& Ahmad, W. (2006). Evidence of apoptotic effects of 2,4-D and butachlor on walking catfish, Clarias batrachus, by transmission electron microscopy and DNA degradation studies. Life Sciences, 78, 977-986.

Barbieri, E. (2009). Effect of 2,4-D herbicide (2,4dichlorophenoxyaceticacid) on oxygen consumption and 
ammonium excretion of juveniles of Geophagus brasiliensis (Quoy \& Gaimard, 1824) (Osteichthyes, Cichlidae). Ecotoxicology, 18, 55-60.

Bécaert, V., Samson, R., \& Deschênes, L. (2006). Effect of 2,4-D contamination on soil functional stability evaluated using the relative soil stability index (RSSI). Chemosphere, 64, 17131721.

Benli, A. Ç. K., Sarakaya, R., Sepici-Dincel, A., Selvi, M., Sahin, D., \& Erkoc, F. (2007). Investigation of acute toxicity of (2,4dichlorophenoxy) acetic acid (2,4-D) herbicide on crayfish (Astacus leptodactylus Esch. 1823). Pesticide Biochemistry and Physiology, 88, 296-299.

Bovey, R. W., \& Young, A. L. (1980). The science of 2, 4, 5-T, and associated phenoxy herbicides. New York: Wiley.

Burns, C. J., \& SWAEN, G. M. H. (2012). Review of 2,4dichlorophenoxyacetic acid (2,4-D) biomonitoring and epidemiology. Critical Reviews in Toxicology, 42, 768-786.

Caldas, E., \& Souza, L. C. (2000). Avaliação de risco crônico da ingestão de resíduos de pesticidas na dieta brasileira. Revista Saúde Pública, 34, 529-537.

Cattaneo, R., Loro, V. L., Spanevello, R., Silveira, F. A., Luz, L., Miron, D. S., et al. (2008). Metabolic and histological parameters of silver catfish (Rhamdia quelen) exposed to commercial formulation of 2,4-dichlorophenoxiacetic acid (2,4D) herbicide. Pesticide Biochemistry and Physiology, 92, 133-137.

Cenkci, S., Yildiz, M., Cigerci, I. H., Bozdag, A., Terzi, H., \& Terzi, E. S. A. (2010). Evaluation of 2,4-D and dicamba genotoxicity in bean seedlings using comet and RAPD assays. Ecotoxicology and Environmental Safety, 73, 15581564.

Chingombe, P., Saha, B., \& Wakeman, R. J. (2006). Effect of surface modification of activated carbon on the sorption of 2 , 4-dichlrophenoxyacetic acid and benazolin from water. Journal of Colloid and Interface Science, 297, 434-442.

Colosio, C., \& Moretto, A. (2008). Pesticides. In K. Heggenhougen \& S. R. Quah (Eds.), International encyclopedia of public health (pp. 59-66). San Diego: Academic.

Correia, F. V., \& Moreira, J. C. (2010). Effects of glyphosate and 2, 4-D on earthworms (Eisenia fetida) in laboratory tests. Bulletin of Environmental Contamination and Toxicology, 85, 264-268.

Costa, C. R., \& Olivi, P. (2008). A toxicidade em ambientes aquáticos: discussão e métodos de avaliação. Quimica Nova, 31, 1820-1830.

Croker, B. H. (1953). Effects of 2,4-D dichlorophenoacetic acid and 2,4,5- trichlorophenoxyacetic acid on mitosis in Allium cepa. Botanical Gazette, 114, 274-283.

de Souza, C. P., Guedes, T., \& Fontanetti, C. S. (2016). Evaluation of herbicides action on plant bioindicators by genetic biomarkers: a review. Environmental Monitoring and Assessment, 188, 694.

Erne, K. (1966). Distribution and elimination of chlorinatedphenoxyacetic acids in animals. Acta Veterinaria Scandinavica, 7, 240-256.

Filkowski, J., Besplug, J., Burke, P., Kovalchuk, I., \& Kovalchuk, O. (2003). Genotoxicity of 2,4-D and dicamba revealed by transgenic Arabidopsis thaliana plants harboring recombination and point mutation markers. Mutation Research, 542, 23-32.
Fiskesjö, C. G., Lassem, C., \& Renberg, L. (1981). Chlorinated phenoxyacetic acids and chlorophenols. In the modified Allium test. Chemico-Biological Interactions, 34, 333-344.

Fonseca, M. B., Glusczak, L., Moraes, B. S., Menezes, C. C., Pretto, A., Tierno, M. A., et al. (2008). The 2,4-D herbicide effects on acetylcholinesterase activity and metabolic parameters of piava freshwater fish (Leporinus obtusidens). Ecotoxicology and Environmental Safety, 69, 416-420.

Gallagher, E., \& Di Giulio, R. (1991). Effects of 2,4-D dichlophenoxyacetic acid and picloran on biotransformation, peroxisomal and serum enzyme activities in channel catfish (Ictalurus punctatus). Toxicology Letters, 57, 65-72.

Garabrant, D. H., \& Philbert, M. A. (2002). Review of 2,4dichlorophenoxyacetic acid (2,4-D) epidemiology and toxicology. Critical Reviews in Toxicology, 32, 233-257.

Geras'kin, S. A., Kim, J. K., Dikarev, V. G., Oudalova, A. A., Dikareva, N. S., \& Spirin, Y. V. (2005). Cytogenetic effects of combined radioactive $(137 \mathrm{Cs})$ and chemical $(\mathrm{Cd}, \mathrm{Pb}$, and 2 , 4-D herbicide) contamination on spring barley intercalar meristem cells. Mutation Research, 586, 147-159.

Gorzinski, S. J., Kociba, R. J., Campbell, R. A., Smith, F. A., Nolan, R. J., \& Eisnenbrandt, D. L. (1987). Acute, pharmacokinetic, and subchronic toxicological studies of 2,4dichlorophenoxyacetic acid. Fundamental and Applied Toxicology, 9, 423-435.

Grabinska-Sotaa, E., Wisniowska, E., \& Kalka, J. (2003). Toxicity of selected synthetic auxines - 2,4-D and MCPA derivatives to broad-leaved and cereal plants. Crop Protection, 22, 355360 .

Gressel, J. (2011). Low pesticide rates may hasten the evolution of resistance by increasing mutation frequencies. Pest Management Science, 67, 253-257.

Grisolia, C. K. (2005). Agrotóxicos: mutação, câncer e reprodução. Brasília: Editora Universidade de Brasília.

Grossmann, K. (2003). Mediation of herbicide effects by hormone interactions. Journal of Plant Growth Regulation, 22, 109 122.

Gul, T., Kaymak, F., \& Muranli, F. D. G. (2006). Genotoxic effects of Avenoxan on Allium cepa L. and Allium sativum L. Caryologia, 59, 241-247.

Heggstrom, M. J. (2009). The sublethal effects of 2,4-D dimethylamine on wood frog tadpoles in Saskatchewan. Thesis Master of Science. University of Saskatchewan. Canada.

Holt, M. S. (2000). Sources of chemical contaminants and routes into the freshwater environment. Food and Chemical Toxicology, 38, S21-S27.

Hoy, J. B. (1985). Toxicity of 2,4-D to millipeds (Polydesmidae: Diplopoda): food contamination and residue distribution as factors. Journal of Economic Entomology, 78, 302-304.

IBAMA - Instituto Brasileiro do Meio Ambiente dos Recursos Naturais Renováveis. (2016). Boletins, 2009-2014: Vendas de ingredientes ativos por UF.http://www.ibama.gov. br/areas-tematicas-qa/relatorios-de-comercializacao-deagrotoxicos/pagina-3. Accessed 04 Aug 2016.

Iqbal, M. (2016). Vicia faba bioassay for environmental toxicity monitoring: a review. Chemosphere, 144, 785-802.

Itoh, K., Kinoshita, M., Morishita, S., Chida, M., \& Suyama, K. (2013). Characterization of 2,4-dichlorophenoxyacetic acid and 2,4,5-trichlorophenoxyacetic acid-degrading fungi in 
Vietnamese soils. FEMS Microbiology Ecology, 84, 124 132.

Kale, P. G., Petty, B. T., Walker, S., Ford, J. B., Dehkordi, N., Tarasia, S., et al. (1995). Mutagenicity testing of nine herbicides and pesticides currently used in agriculture. Environmental and Molecular Mutagenesis, 25, 148-153.

Kelley, K. B., \& Riechers, D. E. (2007). Recent developments in auxin biology and new opportunities for auxinic herbicide research. Pesticide Biochemistry and Physiology, 89, 1-11.

Kennepohl, E., \& Munro, I. C. (2001). Phenoxy herbicides (2,4D). In R. I. Krieger \& W. C. Krieger (Eds.), Handbook of pesticide toxicology (pp. 1623-1638). San Diego: Academic.

Klaassen, C. D. (2013). Casarett and Doull's toxicology: the basic science of poisons (8th ed.). New York: McGraw-Hill.

Knopp, D., \& Schiller, F. (1992). Oral and dermal application of 2, 4-dichlorophenoxyacetic acid sodium and dimethylamine salts to male rats: investigations on absorption and excretion as well as induction of hepatic mixed-function oxidase activities. Archives of Toxicology, 66, 170-174.

Kumar, S., Arya, S. K., Roy, B. K., \& Singh, A. K. (2010). The effects of 2,4-dichlorophenoxy acetic acid and isoproturon herbicides on the mitotic activity of wheat (Triticum aestivum L.) root tips. Turkish Journal of Biology, 34, 55-66.

Kumari, T. S., \& Vaidyanath, K. (1989). Testing of genotoxic effects of 2,4-dichlorophenoxyacetic acid (2,4-D) using multiple genetic assay systems of plants. Mutation Research, 226, 235-238.

Leme, D. M., \& Marin-Morales, M. A. (2009). Allium cepa test in environmental monitoring: a review on its application. Mutation Research, 682, 71-81.

Ma, T. H., Xu, Z., Xu, C., Mc Connell, H., Rabago, E. V., Arreola, G. A., et al. (1995). The improved Allium/Vicia root tip micronucleus assay for clastogenicity of environmental pollutants. Mutation Research, 334, 185-195.

MAPA-Ministério da Agricultura, Pecuária e Abastecimento. Instituto Brasileiro do (2017). http://agrofit.agricultura.gov. br/agrofit_cons/principal_agrofit_cons. Accessed 18 Jan 2017.

Marin-Morales, M., Ventura-Camargo, B. C., \& Hoshina, M. M. (2013). Toxicity of herbicides: impact on aquatic and soil biota and human health. In A. J. Price \& J. A. Kelton (Eds.), Herbicides-current research and case studies in use (pp. 399-443). Rijeka: In Tech.

MarrónMontiel, E., Ruiz-Ordaz, N., Rubio-Granados, C., JuárezRamírez, C., \& Galíndez-Mayer, C. J. (2006). 2,4-D degrading bacterial consortium. Isolation, kinetic characterization in batch and continuous culture and application for bioaugmentating an activated sludge microbial community. Process Biochemistry, 41, 1521-1528.

Mičić, M., Bihari, N., \& Mlinarič-Raščan, I. (2004). Influence of herbicide, 2,4-dichlorophenoxy acetic acid, on haemocyte DNA of in vivo treated mussel. Journal of Experimental Marine Biology and Ecology, 311, 157-169.

Mortelmans, K., Haworth, S., Speck, W., \& Zeiger, E. (1984). Mutagenicity testing of agent orange components and related chemicals. Toxicology and Applied Pharmacology, 75, 137146.

Mustonem, R., Kangas, J., Vuojolahti, P., \& Linnainmma, K. (1986). Effects of phenoxyacetic acids on the induction of chromosome aberrations in vitro and in vivo. Mutagenesis, $16,37-48$.
Obidike, I. R., Aka, L. O., Omoja, V. U., Shoyinka, S. V. O., Kamalu, T., \& Nanika, S. M. (2012). Testicular morphology and antispermatogenic effects of 2,4-dichlorophenoxyacetic acid (2,4-D) in male West African Dwarf (WAD) goats. Comparative Clinical Pathology, 21, 1457-1462.

Oga, S., Camargo, M. M. A., \& Batistuzzo, J. A. O. (2014). Fundamentos de toxicologia (4th ed.). São Paulo: Atheneu.

Oruç, E. O., Sevgiler, Y., \& Uner, N. (2004). Tissue-specific oxidative stress responses in fish exposed to 2,4-D and azinphosmethyl. Comparative Biochemistry and Physiology-Part C, 137, 43-51.

Pavlica, M., Papes, D., \& Nagy, B. (1991). 2,4Dichlorophenoxyacetic acid causes chromatin and chromosome abnormalities in plant cells and mutation in cultured mammalian cells. Mutation Research, 263, 77-81.

Pazmiño, D. M., Romero-Puertas, M. C., \& Sandalio, L. M. (2012). Insights into the toxicity mechanism of and cell response to the herbicide 2,4-D in plants. Plant Signaling and Behavior, 7, 425-427.

Rodrigues, G. S. (2002). Pesticide mutagenesis. In D. Pimentel (Ed.), Encyclopedia of pest management (pp. 595-597). New York: Marcel Dekker.

Sanches, S. M., Silva, C. H. T. P., Campos, S. X., \& Vieira, E. M. (2003). Pesticidas e seus respectivos riscos associados à contaminação da água. Pesticidas: Ecotoxicologia e Meio Ambiente, 13, 53-58.

Sarikaya, R., \& Selvi, M. (2005). Investigation of acute toxicity of (2,4-dichlorophenoxy) acetic acid (2,4-D) herbicide on larvae and adult Nile tilapia (Oreochromis niloticus L.). Environmental Toxicology and Pharmacology, 20, 264-268.

Sarikaya, R., \& Yilmaz, M. (2003). Investigation of acute toxicity and the effect of 2,4-D (2,4-dichlorophenoxyacetic acid) herbicide on the behavior of the common carp (Cyprinus carpio L., 1758; Pisces, Cyprinidae). Chemosphere, 52, 195-201.

Tayeb, W., Nakbi, A., Trabelsi, M., Attia, N., Miled, A., \& Hammami, M. (2010). Hepatotoxicity induced by sub-acute exposure of rats to 2,4-dichlorophenoxyacetic acid based herbicide "Désormonelourd". Journal of Hazardous Materials, 180, 225-233.

Teixeira, M. C., Duque, P., \& Sá-Correia, I. (2007). Environmental genomics: mechanistic insights into toxicity of and resistance to the herbicide 2,4-D. Trends in Biotechnology, 25, 363370.

Tukula, T. E., \& Jalal, S. M. (1985). Increase rates of sister chromatid exchanges induced by the herbicide 2,4-D. Journal of Heredity, 76, 213-214.

USEPA-United States Environmental Protection Agency. (2005). Reregistration eligibility decision for 2,4-D. Washington, DC: United States Environmental Protections Agency.

Walters, J. (1999). Environmental fate of 2, 4dichlorophenoxyacetic acid. Sacramento: Department of pesticide regulations.

Wang, Y-S., Yen, J-H., Hsieh, Y-N., \& Chen, Y-L. (1994). Dissipation of 2,4-D glyphosate and paraquat in river water. Water, Air, and Soil Pollution, 72, 1-7.

World Health Organization (WHO) (1984). Environmental health criteria 29: 2,4-dichlorophenoxyacetic acid (2,4-D). Switzerland: World Health Organization. 
World Health Organization (WHO) (1997). Pesticide residues in food -1997: joint FAO/WHO meeting on pesticide residues. Part II, ecological and environmental. 2,4-D salts and esters: evaluation of effects on the environment. Switzerland: World Health Organization.

Wolfe, W. H. (1984). The epidemiology and toxicology of agent orange. Dayton, $\mathrm{OH}$ : Proceedings of the 14th Conference on Environmental Toxicology.
Zagatto, P. A., \& Bertoletti, E. (2006). Ecotoxicologia aquática: princípios e aplicações. São Carlos: Rima Artes e Textos.

Zimdahl, R. L. (2010). Chapter 6-development of herbicides after 1945. In R. L. Zimdahl (Ed.), A history of weed science in the United States (pp. 79-113). USA: Elsevier. 